\title{
Occupational safety and health in maritime sector in Morocco 60 years after independence:
}

\section{current state, constraints and prospects}

\section{Omar Laraqui ${ }^{1}$, Nadia Manar ${ }^{2}$, Salwa Laraqui ${ }^{2}$, Tarik Ghailan $^{3}$, Frédéric Deschamps ${ }^{1}$, Chakib El Houssine Laraqui ${ }^{2}$}

\author{
${ }^{1}$ University Institute of Occupational Health and Environmental Medicine of Reims, Cedex, France \\ ${ }^{2}$ Graduate School of Health Engineering, Casablanca, Morocco \\ ${ }^{3}$ Moroccan Society of Maritime Health, Tangier, Morocco
}

\begin{abstract}
Background: The aim of this study was to evaluate the situation 60 years after independence, to assess the current state, to highlight the constraints and to propose recommendations for improving occupational health in the maritime sector.

Materials and methods: This study was based on collecting data of: 1) Legislative texts on occupational health and safety; 2) Statistics from administrations (Ministry of Health and Ministry of Marine Fisheries), general medical council of Morocco, scientific societies and associations of occupational health and maritime medicine; 3) Analysis of a self-questionnaire sent to 22 physicians working in fishermen's health services and listed in the yearbook 2017 of the Moroccan Society of Maritime Medicine. It included five sections: socio-demographic and professional characteristics, training, assessment of activities, constraints in their exercise and ten priority recommendations to improve the situation.

Results: Health and safety in maritime sector are progressing since the Labour Code of 2004 and the Convention of December 27, 1996 between the Ministry of Health and the Ministry of Marine Fisheries. It concerns the organisation of a fishermen's health prevention with the establishment of the fishermen's health office at central level and fishermen's health services at the main ports. However, medical coverage is still insufficient. Maritime medicine remains an unattractive specialty because the physicians are a poorly paid and have some difficult working conditions.

Conclusions: The absence of up-to-date synthetic data on safety and health in maritime sectors led us to carry out this study, which showed some dysfunctions and deficiencies that hinder the promotion of workers' health in this sector. The recommendations proposed by the physicians should be the backbone of any improvement related to occupational health and safety. It is the practitioners themselves who, faced with their practice, are the best able to disseminate a reflection qualified as ethical, which cannot be dissociated from their everyday activities.
\end{abstract}

(Int Marit Health 2018; 69, 2: 110-117)

Key words: maritime sector, safety, health, Morocco

\section{INTRODUCTION}

Morocco has an important maritime coast with two Mediterranean and Atlantic facades, a coastline stretching over $3500 \mathrm{~km}$ and a maritime area of about 1.2 million $\mathrm{km}^{2}$. It has a large network of 38 ports with 13 international trade ports, 19 fishing ports and 6 marinas. It also has dozens of fishing sites set up in fishing villages or in landings designed for artisanal fishing. The marine sector provides nearly 140,000 direct jobs: 120,000 in the fishing sector, 10,000 in the merchant marine and 10,000 in the port [1].

Dr. Chakib El Houssine Laraqui, Graduate School of Health Engineering, 24 rue Lafontaine, Quartier Racine, 20100 Casablanca, Morocco, e-mail: chlaraqui51@gmail.com 
Occupational health and safety is a fundamental right for all workers in Morocco. Article 31 of the 2011 Constitution [2] guarantees everyone access to the conditions for enjoying the rights to health care, social protection, medical coverage, solidarity and work. The Joint Committee of the International Labour Organisation and the World Health Organisation has defined the objectives of occupational health $[3,4]$ :

- to promote and maintain the highest degree of physical, mental and social well-being of workers in all occupations;

- to prevent any damage to their health caused by working conditions.

To protect them in their use against the risks resulting from the presence of agents prejudicial to their health; place and maintain the worker in a job appropriate to his physiological and psychological abilities.

Since Morocco's independence in 1956, occupational hazards have emerged as a concern for governments, employers and labour unions. Marked by its legacy of French occupational safety and health legislation, this led to the development of the labour inspection for the control, the insurance system for the occupational hazards compensation and the occupational medicine services for the medical prevention (pre-employment, follow up and periodic visits) and the improvement of working conditions [3-5]. According to the Code of Labour Law, the workers on land in the port enterprises are subject to the legislation on the organisation of occupational medicine since 1957 [6]. Legislation for seafarers' health goes back to 1919 with the Law of Maritime trade, which were modified and completed by the law of July 16, 2010 [7]. In 1998, the Maritime Fisheries Department was separated from the Ministry of Transport and was affected to the Minister of Agriculture. The physicians, who were appointed by the Ministry of Transport, became responsible only for merchant seafarers.

At the same time, the Department of Fishing has signed a convention with the Ministry of Health to set up medical services for fishermen at fishing ports to enable them to benefit medical coverage. Nevertheless, the fisheries sector benefits from structured and systematised medical coverage only since the joint convention of 1996 between the Ministry of Health and the Ministry of Fisheries [8]. Although the profession of the fisherman is universally recognised as one of the most dangerous occupations [9]. In France, in 2007 , when there were 40 occupational accidents per 1000 employees on land, there were 121 occupational accidents per 1000 seafarers in the fisheries sector. The figures were even more eloquent when one observed the number of deaths by falling at sea or by sinking: a fisherman was about 44 times more likely to die at work than workers on land [10]. The 2014 record of occupational accidents in the maritime sector in France showed that the case fatality rate was 5 times higher than in the construction sector and that the majority of fatal accidents involved fishermen. The mortality rate for occupational accidents at sea was $1.18 \%$ compared with $0.03 \%$ on land; the frequency was almost 40 times greater [11]. The situation was more alarming in some regions of the world. The figures provided at the Third Spanish-French Maritime Medical Congress, held in Agadir in 2009, spoke for themselves: there were between 90 and 150 fatal occupational accidents per 100,000 fishermen in the world. In West Africa, this figure would be between 300 and 1000 and in South Africa it would be about 600 [10]. In the coastal fishery sector in Morocco, fatal occupational accidents accounted for $14.2 \%$ of occupational accidents in 2007 and 2008 [12]. Several studies carried out among traditional fishermen in Morocco suggest that they take many avoidable risks [13-16]. The absence of up-to-date synthetic data on safety and health in maritime sectors led us to carry out this study. Its aim was to report the current state, to assess the current state, to highlight constraints and to propose recommendations for improving occupational health in the maritime sector.

\section{MATERIALS AND METHODS}

This study was based on collecting data of:

- legislative texts on occupational health and safety;

- statistics from administrations (Ministry of Health and Ministry of Marine Fisheries), general medical council, scientific societies of occupational health and maritime medicine;

- analysis of a self-questionnaire sent to 22 physicians working in seafarers' health services and listed in the yearbook 2017 of the Moroccan Society of Maritime Medicine. It included five sections: socio-demographic and professional characteristics, training, assessment of activities, constraints in their exercise and ten main recommendations to improve the situation.

\section{FISHING SECTOR}

\section{RESULTS}

\section{Socio-economic and socio-demographic data}

The fleet comprises about 18,000 boats: 310 for deepsea fishing, 1750 for inshore fishing and 15,940 for artisanal fishing. The fishing sector occupies an important place in the economy of Morocco, which is reputed among the most fish-rich areas in the world with catches of more than 1 million tons. It ranks first among fish producers in Africa and $25^{\text {th }}$ in the world. It is also the world's largest exporter of sardines. The sector contributes from $2 \%$ to $3 \%$ of gross domestic product. Moroccan seafood exports registered nearly \$ 1.59 billion (2014), contributing 58\% to agro-food exports. The sector's turnover has grown at an average annual rate of $5 \%$ since 2001 . 
The sector provides nearly 565,000 jobs including 450,000 indirect, and 115,000 direct jobs which account for 109,000 in fishing (7100 deep-sea, 60,000 inshore, 41,900 artisanal fishermen) and 6000 in the industry.

\section{Control and management organisations}

At the central level, the fisheries sector includes six directorates: marine fisheries, maritime fishing industries, control of the activities of sea fishing, maritime training of fishermen and rescue, general and legal affairs, strategies and cooperation. At the peripheral level, the 18 delegations execute the ministry program across the national coast.

Four maritime fisheries chambers (Mediterranean, North Atlantic, Central Atlantic and South Atlantic) represent the marine fisheries sectors nearby the public authorities. They are grouped together within the Federation of Maritime Fisheries Chambers, which gives advices and information to the government and presents proposals on all matters concerning marine fisheries.

Several associations of fishermen and maritime ship-owners participate in health and safety field.

\section{Development and training organisations}

The training of fishermen is done either on the ground in a traditional way with a spokesman (usually a parent) or in vocational training schools. Fourteen maritime training establishments certify the conduct, operation and maintenance of fishing vessels:

- 1 High Institute of Maritime Fisheries in Agadir;

- 5 Marine Fisheries Technology Institutes in Al Hoceima, Larache, Safi, Tan-Tan, Laayoune;

- 8 Maritime Professional Qualification Centres in Nador, Tangiers, Casablanca, Essaoiura, Agadir, Sidi Ifni, Boujdour and Dakhla.

\section{Organisation of fishermen's health and safety}

The Convention of December 27, 1996 between the Ministry of Health and the Ministry of Marine Fisheries concerns the organisation of a fishermen's health prevention with the establishment of the fishermen's health office at central level and fishermen's health services at the main ports. On June 1, 1999, the first service was created in Tangier. The joint February 21, 2005, circular issued by the Ministry of Marine Fisheries and the Ministry of Health concerns the establishment of a marine health prevention programme.

The fishermen's health office. It is under the authority of a chief medical officer who works in close collaboration with the Ministry of Maritime Fisheries (Directorate of maritime training of seafarers and rescue), and the Ministry of Health (Directorate of epidemiology and disease control). Its missions include:
- definition of technical programmes and the study of health services' needs;

- organisation and supervision of health services' activities;

- contribution to the development of information and awareness programmes on maritime hazards and health education;

- collection and exploitation of statistical data relating to fishermen's health;

- carrying out epidemiological studies on maritime hazards;

- participation in the training for medical and paramedical staff of health services;

- participation in the training for fishermen in emergency care and first aid at workplace;

- participation in the development of legislation relating to health and safety of fishermen.

Fishermen's health services. Each service is under the authority of a chief medical officer designated by the Ministry of Health. Their missions are preventive medicine, medical care, general hygiene and sanitation.

Preventive medicine includes:

- medical surveillance of fishermen;

- prevention of occupational accidents and diseases;

- improvement of the working conditions of fishermen.

Health care includes medical consultations and emergency first aid for wounded or sick fishermen.

General hygiene and sanitation concern the ports, the boats, the small boats and other dependencies of the ports.

The staff of each service includes a physician, two nurses and a secretary. The necessary medical equipment must allow the physician to perform a clinical examination, biometric measurements, vision control, as well as urine analysis. A wardrobe with medicines and health products needed for first aid and emergency care.

The missions of the chief medical officer of the health service include actions at the workplace and medical supervision.

Actions at the workplace:

- study the organisation, positions and methods of work, with a view to identifying and assessing nuisances, health risks in the workplace, and ensuring a better adaptation of work to skills of fishermen;

- assess the conditions of general hygiene and occupational hygiene, and work organisation factors that may lead to risks to the health of fishermen;

- participate in the surveillance and control of the hygiene and liveability of ships, the living and working conditions on board, as well as the safety of the port and its dependencies;

- provide advice on health, safety and hygiene (individual and collective protective equipment),

- monitor and control the hygiene and general health status of maritime training establishments and teach health, safety and hygiene in these establishments. 
Medical supervision:

- carry out a physical fitness examination of fishermen for hiring and during their career according to an annual programme;

- carry out the medical check-up of fishermen at a maritime training establishment;

- carry out the medical consultation of sick fishermen during the course of their activities or who have been victims of accidents in the workplace;

- provide medical advice by radio for sick, injured or repatriation officers at sea;

- assess the suitability of fishermen for accidents at work or sick leave.

The management of the health services. The organisation, the animation and the management of the health services are in coordination with the delegates of the Ministry of Health and the Ministry of Marine Fisheries.

They keep all medical records of the services (register for medical consultations, medical fitness visits, daily activities, fishermen requiring special supervision, occupational accidents and diseases, observations and recommendations relating to the improvement of hygiene and working conditions). Quarterly report is prepared; copies are sent to the Ministry of Health and the Ministry of Marine Fisheries. These quarterly reports are consolidated into an annual report, which is also sent to the same recipients.

\section{Assessments of the medical activities of fishermen's health services}

We analysed all the self-questionnaires sent to all physicians working in fishermen's health services. They all answered the questionnaire.

a) There are 20 fishermen's health services with 22 physicians and 12 nurses. The ports concerned are Nador, RasKebdana, Al Houceima, Jebha, M'diq, Fnideq, Tangier, Larache, Casablanca, Kenitra, El Jadida, Safi, Agadir, Tan Tan, Tarfaya, Laayoune, Dakhla, Essaouira and Sidi Ifni, Boujdour.

b) Medical visits and awareness campaigns. The care consultations were 9243 and the paramedical care were 11,003 . The emergency treatment for work-related injuries was 653. The occupational medical visits were 44,267 (16,015 pre-employment visits and 28,252 follow up or periodic visits. Only $36.9 \%$ of fishermen have benefited from occupational medical visits. According to the physicians, the ten most frequent pathologies were respiratory diseases for $95.5 \%$, musculoskeletal disorders for $59.1 \%$, dermatoses for $54.5 \%$, arterial hypertension for $54.5 \%$, ear, noses and throat illnesses for $36.4 \%$, diabetes for $36.4 \%$, sexually transmitted infections for $36.4 \%$, digestive disorders for $36.4 \%$, sleep disorders for $31.8 \%$ and wounds and injuries for
$27.3 \%$. In addition to medical visits, $67 \%$ of physicians conducted information, education and communication campaigns on tobacco, AIDS, musculoskeletal disorders, diabetes, viral hepatitis, tuberculosis, hygiene, and/or first aid at workplace.

c) Socio-professional characteristics and training of seafarers' physicians. All physicians were from the public sector and had chosen to work in the health services of seafarers. The average age was $47.6 \pm 9.3$ years and $81 \%$ were males. Average seniority in the Ministry of Health was $14 \pm 4.7$ years and within fishermen's health services was $7.9 \pm 3.4$ years. Of all the physicians surveyed, only $40.9 \%$ were full-time fishermen's health services and $38 \%$ were specialists in occupational medicine. $19 \%$ had a degree in sports medicine and none had a diploma in maritime medicine. $67 \%$ were unhappy or dissatisfied of their training. Continuing medical training or education was for $81 \%$ in the form of participation in conferences and $57 \%$ had associative activities.

d) Conditions of exercise. Working conditions were judged poor or unsatisfactory by $62 \%$ of physicians. The state of the equipment made available to the physicians was considered bad by $43 \%$. The feeling of being useful "often or permanently" was reported by $95 \%$. Occupational stress was felt "often or permanently" by $72 \%$. The wages was not suitable for $62 \%$. The technical time (inspection of boat hygiene) was made only by $19 \%$ and only $44 \%$ have collaborated with the health, safety, environment services.

\section{Main recommendations proposed by the} physicians of fishermen's health services

The most frequent recommendations are to:

- improve the work conditions of personnel (physicians, nurses and staff) of fishermen's health services;

- rise physicians' and nurses' salaries (wages);

- increase the number of seafarers' health services to cover all fishermen;

- ensure and to generalise the health monitoring of all fishermen and hygiene at the workplace;

- establish a diploma in marine medicine and continuing training for medical and paramedical personnel;

- expand the multi-disciplinary: coordination between the physicians and the other health and safety officers;

- dedicate these qualified personnel exclusively to fishermen's health services.

\section{SECTOR OF THE MERCHANT NAVY Socio-economic data}

Maritime freight transport is the mainstay of foreign trade and a strategic vector of the Moroccan economy. More than $95 \%$ of foreign trade uses the seaway. Excluding 
ancillary activities, the sector contributes $1 \%$ to $1.5 \%$ of GDP and Moroccan shipping companies provide $0.3 \%$ of GDP. The total number of jobs in this sector represents 10,000 people, half of whom work in port terminals.

The maritime transport of passengers and vehicles is of an economic and social nature. Most of the passengers are Moroccans living abroad. The most important passenger shipping is located in the Strait of Gibraltar between Morocco and Spain. A combination of vessels under the flag of Morocco (IMTC, FRS Morocco and Inter Shipping) and abroad Acciona Trasmediterranea, Euroferrys, FRS Iberia and Balearia offer these services. About 4 million passengers and 1 million vehicles transit annually.

\section{Training for human resources}

The Higher Institute of Maritime Studies (Institut Supérieur d'Etudes Maritimes: ISEM), under the Ministry of Equipment, is responsible for training senior managers in various branches of the maritime industry, conducting studies and research and contributing to lifelong learning, and staff development.

\section{Organisation of occupational health and safety services}

Companies operating in this sector are subject to the laws and regulations relating to the establishment of occupational medical services provided for in the Labour Code for people who don't sail. Seafarers are subject to the Code of Law of Maritime Trade 1919 and its implementing regulations. Morocco's ratification of the Maritime Labour Convention, drafted in 2006, imposes requirements for the protection of health and the medical care of seafarers. According to this convention, every vessel must dispense with a medicine chest, medical equipment and a medical guide. Every ship carrying 100 or more persons on board or normally engaged in international voyages of more than 3 days shall have a qualified medical officer. Vessels without a doctor on board must have at least one seafarer responsible for medical care and the administration of medicinal products as part of their normal duties or a seafarer capable of administering first aid. Medical consultations by radio or satellite, including specialist advice, should be available for seagoing vessels at all times.

In Morocco, the doctors on board are general practitioners contracted by the liberal sector who have completed the Standards of Training, Certification, and Watchkeeping code course. On the ground, for seafarers the Merchant Marine Directorate give special authorisation for general practitioners who are able to issue certificate of medical fitness.

The Tangier Maritime Traffic Control Centre (MTCC) commonly called the Tangier Vessel Traffic Services (VTS) contributes to improving the maritime traffic efficiency and protection, assesses the situation in order to prevent accidents, promotes maritime safety and security and protects the marine environment in the Gibraltar Strait. The area in one of the busiest routes, especially for the largest tankers in the world.

\section{PORT SECTOR (QUAY STAFF)}

The ports, which account for 95\% of the Kingdom's external trade, are a vital sector for the economy. The national port sector is organised into three main functions. The sovereign function includes the definition and the implementation of the port policy, the planning and the realisation of new port infrastructures. The Department of Ports and the Public Maritime Domain under the Ministry of Equipment and Transport provide it. The port authority function includes the port police, the regulation, the granting and the monitoring of the concessions and the authorisations of exercise of the port activities. It is provided by the National Ports Agency with the exception of the port Tangier-Med managed by the Tangier Med Port Authority S.A. "TMPA".

The commercial functions are entrusted to private or public entities as operators or service providers under concessions or authorisations such as Marsa Maroc, Somaport, APM Terminal, Eurogate, etc. Marsa Maroc is the leading company in the operation of port terminals. It is present in 9 ports where it offers handling, storage and logistics services as well as services to ships.

\section{Socio-economic data}

The port sector knows a development and makes it possible to position Morocco as essential pivot in the Euro-Mediterranean space notably thanks to the port Tangier-Med. The overall volume of port activity reached 115.1 million tons, of which 20 million tons relates to transshipment (2013). Port operating companies directly employ approximately 4000 employees.

Port activity managed by the National Ports Agency (Agence Nationale des Ports, ANP):

- 75.8 million tons: imports 47.8 million tons and exports 28 million tons;

- 4.1 million containers, Twenty-foot Equivalent Unit (TEU);

- products: cereals (7.6 million tons), phosphate and drift (23.8 million tons), shot volume (228855 units), vehicles (320986 units), hydrocarbons and energy products (16.5 million tons), coal and cokes (7.9 million tons);

- cruise passenger traffic and passengers (4.4 million).

\section{Organisation of occupational health services}

According to the Labour Code, port companies are subject to the legislation on the organisation of occupational medicine. Each company has a self-employed medical ser- 
vice located within the port and managed by one or more medical specialists in occupational medicine who provide preventive medicine. These services employ nurses and social workers. The nurses provide a 24-hour guard service.

Some companies make available to its employees a network of health centres and dental centres dedicated to care.

\section{EMERGENCY MARINE MEDICINE}

Medical aid at sea is based on tele-medical consultation and assistance for ships at sea to deal with any situation of human distress occurring among crewmembers, passengers or occupants. a merchant, fishing or pleasure vessel. While waiting to develop its own telemedicine, Morocco is working with its neighbours, especially in Spain and France, to save lives at sea. These operations are operated by:

- the Spanish radio medical service: "El Servicio Radio-Médico (SRM)";

- the French Maritime Medical Consultation service in Toulouse: "Tele Medical Assistance Service (TMAS)";

- the French maritime medical coordination in Brest, Le Havre, Bayonne and Toulon provides emergency medical aid at sea: "Samu de coordination médicale maritime (SCMM)";

- maritime radio links between the vessel and the consultation centre;

- the operational device for medical assistance;

- the Search and Rescue (SAR) mission of life at sea is an obligation of coastal States. This mission is entrusted to the Department of Maritime Fisheries and is based on a national system that relies on a Coordination Centre and intervention resources including a dedicated rescue fleet. The Marine Fisheries Department is responsible for establishing, developing and maintaining maritime search and rescue organisations in Morocco. The Minister directs the Maritime SAR policy, international agreements, conventions and operational matters pertaining to Maritime SAR. The Marine Fisheries Department is the SAR authority for maritime incidents and is responsible for the provision of Maritime SAR service within the Moroccan Maritime Search and Rescue Region. Also it co-ordinates, liaises, trains, equips, staffs, maintains, prepares finance, develops procedures and operations plans and conducts exercises for Maritime SAR [17].

\section{HYPERBARIC WORKS AND DIVING ACTIVITIES}

The law governing medical fitness to dive dates from 1962 [18]. It allows the medical examination of the fitness to the diving to any doctor without specifying a special qualification for the practitioner. The examination includes a clinical examination and a chest X-ray with an advice of specialist in case of doubt about the fitness.

\section{EVENTS TO PROMOTE OCCUPATIONAL HEALTH AND SAFETY FOR SEAFARERS}

Morocco was organising many events:

- Moroccan days for marine health, organised by the Department of Fisheries of Morocco, were taking place in Agadir in 2004, 2005, 2006, 2007, 2008 and 2010;

- National Congresses of Maritime Medicine organised by the Moroccan Society of Maritime Medicine: The first congress was taking place in Agadir in 2014, the second and the third in Tangier (2015 and 2016) and the fourth in Dakhla in 2017, the fifth will take place in Assilah in November 2018 with the 12th International Hispano Francophone Congress;

- Morocco organised also three sessions of the International Hispano Francophone Congress: the third in Agadir in 2009, the sixth in Tangier in 2012 and the ninth in Agadir in 2015.

Since its creation in 2013, the Moroccan Society for Maritime Medicine promotes the training of the seafarers' physicians and the other partners in the field of maritime health and safety. It benefits from the support of the Spanish and French Societies for Maritime Medicine and of the International Maritime Health Association (IMHA).

Many conferences dealing with the safety and sustainable development in maritime activities:

- Conference on Security and Maritime and Air Safety organised by the Moroccan Association of Maritime and Air Law (Association Marocaine de Droit Maritime et Aérien, AMDMA) on April 14, 2015. The following topics were discussed: International Ship and Port Facility Security (ISPS), Security and Safety of Ports, Responsibilities in terms of maritime safety and security;

- Port Efficiency Forum Morocco 2015 organised by Port Finance International (PFI) in Casablanca on February 25 and 26,2015 . Among the topics covered, we find the safety of port equipment and the prevention of losses risk management.

\section{DISCUSSION}

Morocco ratified many international conventions [19, 20]:

- convention for the unification of some rules on maritime assistance and salvage of September 23, 1910;

- convention for assistance and rescue of January $1^{\text {st }}$, 1972 modified on January $1^{\text {st }}, 1975$ of Boulogne;

- international convention on assistance of April 28, 1989;

- international sanitary regulations adopted by the Twenty-second World Health Assembly on July 25, 1969 in Boston;

- Maritime Labour Convention 2006 of September 10, 2012;

- Work in Fishing Convention 2007 no. 188 of May 16, 2013. Moroccan legislation of health and safety of maritime sector is numerous but scattered and difficult to retrieve and consult. The development and the publication of a Labour Code for the seafarers, bringing together all the laws, 
regulations and conventions, will make them accessible to everyone. Several pieces of legislation are old and must be updated, especially that on hyperbaric work.

The most important recommendations are the application of the health's legislation for all workers in ports and seafarers and the improvement of the working conditions of health professionals. The first one will improve the occupational medical coverage rate and the second the quality of benefits. The evolution and development of the health system and the prevention of occupational risks among fishermen require the consideration and application of the propositions of the physicians surveyed. In our survey, the medical coverage of fishermen remains partial because only $42.5 \%$ have received a medical visit. $59.1 \%$ practiced parttime seafarers medicine concomitantly with public health. Maritime medicine was unattractive: wages were "unsuitable" for $62 \%$, working conditions "were not suitable" for $43 \%$. Work stress was felt often or permanently among $72 \%$.

Awareness raising on issues related to occupational safety and health is improving thanks to the numerous events and symposiums and to a certain awareness of the competent authorities (Ministry of Fisheries, Ministry of Health, Fisheries Chambers etc.). However, there is a lack of commitment of some employee representatives, and of some employers despite their legal responsibility for the protection of employees' health: articles 749 and 750 of Civil Law (code of obligations and contracts) and article 281 of the Labour Code [3].

Prevention structures remain weakened by the secondary prevention logic. This is explained by the frequent absence of other prevention specialists (ergonomists, occupational psychologists or safety engineers) in this sector. The functioning of the majority of fishermen's health services was flawed because there was few or no hygiene's activities on ship. In our study, only 19\% performed them and $44 \%$ collaborated with the health-safety-environment services. There was a difference and a gap between legislative text-conventions and practice on field. We reports below the strong and the weak points of safety and health in the maritime sector and some priority recommendations for improving them.

\section{SOME STRONG POINTS OF HEALTH AND SAFETY IN THE MARITIME SECTOR}

- Ratification by Morocco of the Maritime Labour Convention;

- Plans for the durable development of a new dynamic of the port and maritime sector with investments, new ports and infrastructures;

Ibhar programme includes the modernisation of the coastal and artisanal fleets with actions to improve the living, working and safety conditions on board [21].
"Halieutis plan" consists of the development of a new dynamic in the fisheries sector [22]. This plan is based on three strategic thrusts, namely:

- sustainability: the sustainability of the sector for future generations;

- performance: efficient management of the equipment and infrastructure as well as landing and the establishment of a mechanism for quality control that guarantees access to products with a high level of security plans, hygiene and health for consumers;

- competitiveness: offer products attractively priced and competitive, facilitating access of industrial raw materials and focusing on the most promising markets;

- coordination between the Ministry of Health and the Department of Marine Fisheries to organise preventive medicine for fishermen;

- fairly distribution of fishermen's health services;

- performing health services at most port operators (prevention and health promotion programmes);

- existence of structures dedicated to safety and the environment in ports;

- existence of a regional search and rescue system;

- scientific researches in the field of safety and security amongst seafarers and fishermen;

- coaching and training of seafarers' physicians by the Moroccan Society of Maritime Medicine.

\section{SOME WEAK POINTS OF HEALTH AND SAFETY IN THE MARITIME SECTOR}

- Lack of guidance or recommendation on health and safety management on board ships;

- Difficulty of ensuring visits at workplaces (ports and boats) by the physicians of the health services;

- Insufficient coordination between the maritime inspectors and the physicians of the health services;

- Important turnover of the health staff, which disrupts the good monitoring of the health services;

- Insufficient first aid and first aid training for seafarers in accordance with the International Maritime Organisation (IMO) requirements;

- Lack of specialised occupational health training for seafarers;

- Maritime Labour Convention 2006, International Labour Organisation (MLC 2006, ILO) convention none extended to the fishing sector;

- Persistence of an old legislation of hyperbaric works and diving activities;

- Absence of specialised training in the field of marine medicine for seafarers' physicians;

- Lack of Moroccan system for telemedicine dedicated to the seafarers;

- Insufficiency of the number of hyperbaric chamber rooms across the ports. 


\section{SOME PRIORITY RECOMMENDATIONS FOR IMPROVING HEALTH AND SAFETY IN THE MARITIME SECTOR}

a) At the normative level:

- strengthen the joint circular with a regulatory text specific to health and safety for seafarers that incorporates the requirements of the international maritime convention;

- publish guidelines for the management of occupational health and safety in ships.

b) Prevention medicine for fishermen:

- increase the number of fishermen's health services to cover all ports and fishermen;

- establish initial diploma training and continuing training in marine medicine for medical and paramedical personnel;

- dedicate these qualified personnel specifically and exclusively to seafarers' health centres to ensure a stable health surveillance of seafarers and participate in actions at the workplace;

- coordinate the action of the physicians of health services with other health and safety officers (multi-disciplinary).

c) Occupational medicine in ports:

- the port is an activity zone conducive to the creation of a business-to-business medical service that covers employees of all companies operating in the port. This service will be equipped with a more efficient medical emergency management unit thanks to the pooling of resources.

d) Emergency maritime medicine:

- set up a telemedicine centre for the assistance of people in ships.

e) Hyperbaric works and diving activities:

- update of the legislation of medical fitness for diving;

- establishment of a list of physicians approved for the issue of a certificate of medical fitness for diving;

- increase in the number of hyperbaric rooms to cover the whole kingdom.

\section{CONCLUSIONS}

The absence of up-to-date synthetic data on safety and health in maritime sectors led us to carry out this study, which showed some dysfunctions and deficiencies that hinder the promotion of workers' health in this sector. The recommendations proposed by the physicians should be the backbone of any improvement related to occupational health and safety. It is the practitioners themselves who, faced with their practice, are the best able to disseminate a reflection qualified as ethical, which cannot be dissociated from their everyday activities [23].

\section{REFERENCES}

1. Département de la pêche maritime - Ministère de l'agriculture et de la pêche maritime. http://www.mpm.gov.ma/.

2. Constitution marocaine 2011. Dahir $n^{\circ} 1-11-91$ du 29 juillet 2011 portant promulgation du texte de la constitution publié au bulletin officiel du Royaume du Maroc $n^{\circ} 5964$ bis du 30 juillet 2011. http://
www.amb-maroc.fr/constitution/Nouvelle_Constitution_\%20Maroc 2011.pdf.

3. Laraqui $\mathrm{CH}$. Du droit de la santé des travailleurs au droit à la santé des travailleurs marocains : contraintes et perspectives. Thèse de Doctorat en Droit - Spécialité: droit de la santé (Faculté de droit, Université Lyon 3, 2005; p. 403.

4. Laraqui $\mathrm{CH}$, Laraqui $\mathrm{O}$, Manar N. Guide pratique de droit de la santé et de la sécurité au travail au Maroc. Casablanca: Dar Al Karaouiine, 2016; p. 469.

5. Laraqui $\mathrm{O}$, Laraqui $\mathrm{S}$, Manar $\mathrm{N}$, et al. Santé et sécurité au travail au Maroc 60 ans après l'indépendance: état actuel, contraintes et perspectives. Archives des Maladies Professionnelles et de l'Environnement. 2018; 79(1): 1-9, doi: 10.1016/j.admp.2017.07.004.

6. Loi $n^{\circ} 65-99$ relative au code du travail. http://adala.justice.gov.ma/ production/ legislation/fr/Nouveautes/code\%20du\%20travail.pdf.

7. Loi du 31 mars 1919 relative au code de commerce maritime modified and completed by the law of July 16, 2010. file:///C:/ Users/Administrateur/Downloads/CodedeCommerce Maritime.pdf.

8. Convention de coopération entre le ministère de la Santé et le ministère de la Pêche Maritime. www.mpm.gov.ma/wps/.../L2dBISEvZOFBIS9nQSEh/.

9. Laraqui $\mathrm{O}$, Laraqui S, Manar N, et al. Risk-taking behaviours among fishermen in Morocco by the evaluation of "ordalique" functioning. Int Marit Health. 2017; 68(2): 83-89, doi: 10.5603/ IMH.2017.0016, indexed in Pubmed: 28660610.

10. Kowalski JM. Les marins et la mort. Actualité d'un mythe. La Revue maritime. 2011; 492: 90-102.

11. Accidents du travail et maladies professionnelles maritimes en France, Bilan 2014. http://www.developpement-durable.gouv.fr/ Accidents-du-travail-et-maladies, 46659.html.

12. Ghailan T, Caubet A, Verger $C$, et al. Prévalence des accidents du travail dans le secteur de la pêche côtière au Maroc. Actes des $26 e ̀ m e s$ journées internationales méditerranéennes de médecine de travail. Rennes. 2011.

13. Laraqui $\mathrm{O}$, Laraqui $\mathrm{S}$, Manar $\mathrm{N}$, et al. Prevalence of consumption of addictive substances amongst Moroccan fishermen. Int Marit Health. 2017; 68(1): 19-25, doi: 10.5603/IMH.2017.0004, indexed in Pubmed: 28357832.

14. Laraqui S, Laraqui $\mathrm{O}$, Manar N, et al. The assessment of seafarers' knowledge, attitudes and practices related to STI/HIV/AIDS in northern Morocco. Int Marit Health. 2017; 68(1): 26-30, doi: 10.5603/ IMH.2017.0005, indexed in Pubmed: 28357833.

15. Laraqui O, Hammouda R, Laraqui S, et al. Prevalence of chronic obstructive respiratory diseases amongst fishermen. Int Marit Health. 2018; 69(1): 13-21, doi: 10.5603/IMH.2018.0003, indexed in Pubmed: 29611609.

16. Laraqui $\mathrm{O}$, Manar N, Laraqui S, et al. Prevalence of skin diseases amongst Moroccan fishermen. Int Marit Health. 2018; 69(1): 22-27, doi: 10.5603/IMH.2018.0004, indexed in Pubmed: 29611610.

17. Member Focus: The Moroccan Maritime SAR Organisation. https:// international-maritime-rescue.org/98-lifeline-february-2015-english/1122-member-focus-the-moroccan-maritime-sar-organisation.

18. Joint Order of the Minister of Commerce, Industry, Mines, Crafts and the Merchant Navy and the Minister of Public Health No. 212-61 of July 25,1962 relating to the conditions of physical fitness to be fulfilled for the practice of underwater fishing (BO No. 2604 of 21 September 1962).

19. ILO. Ratified conventions by Morocco. http://www.ilo.org/dyn/normlex/ $\mathrm{fr} / \mathrm{f}$ ? $=$ =NORMLEXPUB:11110:0::NO::P11110_COUNTRY_ID:102993.

20. World health assembly. https://treaties.un.org/doc/Publication/ UNTS/ Volume\%201286/volume-1286--10921-English.pdf.

21. Ibhar program. http://www.mpm.gov.ma/wps/wcm/connect/ e7b2cb74-3668-4c95-b470-b6166085af9b/Programme+lbhar. pdf?MOD=AJPERES.

22. Halieutis program. http://www.maroc.ma/en/content/halieutis.

23. Hervé $C$. Fondements d'une réflexion éthique managériale de santé. Paris: L'Harmattan. 1996: p. 204. 